\title{
THE WITHIN-CATCHMENT INVASION OF THE NON-INDIGENOUS SIGNAL CRAYFISH PACIFASTACUS LENIUSCULUS (DANA), IN UPLAND RIVERS
}

\author{
D.H. BUBB (1), T.J. THOM (2), M.C. LUCAS (1)
}

(1) School of Biological and Biomedical Sciences, University of Durham, Science Laboratories, South Road, Durham, DH1 3LE, UK.

E-Mail: d.h.bubb@durham.ac.uk

(2) Yorkshire Dales National Park Authority, Colvend, Hebden Road, Grassington, North Yorkshire, BD23 5LB, UK.

Reçu le 18 octobre 2004

Accepté le 21 décembre 2004

Received October 18, 2004

Accepted December 21, 2004

\begin{abstract}
The American signal crayfish, Pacifastacus leniusculus, is an invasive species from North America that has been widely introduced through Europe, where it is a major threat to native European crayfish species and causing increasing concern because of its impact on the wider aquatic ecosystem. Although widely considered invasive, little is known of the rates of invasion and colonisation. The temporal and spatial pattern of spread of signal crayfish populations in two upland rivers in Northern England is described. Range expansion of up to $2.4 \mathrm{~km}_{\text {year }}{ }^{-1}$ were recorded from an established population, but rates over an order of magnitude less were recorded in the initial stages of establishment. Range expansion of both populations was strongly biased in a downstream direction, which has implications for directing possible management efforts and determining the timescale of threat which expanding signal crayfish populations pose.
\end{abstract}

Key-words: Pacifastacus leniusculus, Austropotamobius pallipes, freshwater crayfish, colonisation, invasion.

\section{L'INVASION D'UN BASSIN VERSANT PAR L'ÉCREVISSE EXOTIQUE PACIFASTACUS LENIUSCULUS (DANA), EN AMONT DES RIVIĖRES}

\section{RÉSUMÉ}

L'écrevisse américaine, Pacifastacus leniusculus, est une espèce invasive de l'Amérique du Nord qui a envahi largement l'Europe. Cette espèce menace principalement l'espèce indigène européenne, mais aussi l'écosystème aquatique dans son entier. Bien que considérée comme espèce invasive, son taux d'invasion et de colonisation reste peu connu. La colonisation spatio-temporelle de l'écrevisse américaine de deux rivières du Nord de l'Angleterre situées en amont est décrite dans cette étude. L'invasion des populations peut atteindre jusqu'à $2,4 \mathrm{~km}^{\mathrm{an}}{ }^{-1}$; ceci a été mesuré pour une population donnée sachant que ce taux fut plus faible au début de la colonisation. La colonisation spatiale des ces deux populations est fortement biaisée en aval; ceci peut avoir des conséquences dans le contrôle d'efforts de gestion et dans l'établissement de la période de menace d'invasion des populations d'écrevisses américaines. 
Mots-clés: Pacifastacus leniusculus, Austropotamobius pallipes, écrevisse exotiques, invasion.

\section{INTRODUCTION}

Crayfish are among the most widely introduced aquatic invertebrates; their global distribution has been significantly modified by humans $(\mathrm{HOLDICH}, 2002)$. Through a combination of large size, broad feeding habitats and high densities attained, their introduction to new habitats can have a significant impact on the aquatic environment (NYSTRÖM and STRAND, 1996; NYSTRÖM, 2002; DORN and WOJDAK, 2004). The introduction of North American crayfish species into Europe has been partially responsible for severe declines in indigenous European species (HENTTONEN and HUNER, 1999; HOLDICH, ROGERS and REYNOLDS, 1999) through a combination of transfer of crayfish plague Aphanomyces astaci and competitive displacement of native European species.

The signal crayfish is among the most widely introduced crayfish species. Endemic to western North America, it has been introduced to over 20 countries in Europe since the 1960's. The continued spread of signal crayfish within and between catchments is causing further losses of indigenous European crayfish stocks (HOLDICH, ROGERS and READER, 1995) and has the potential for substantial disruption of river ecosystems (GUAN and WILES, 1997; NYSTRÖM, 1999; NYSTRÖM, 2002; STATZNER, PELTRET and TOMANOVA, 2003).

The distribution of non-indigenous crayfish species in Europe has been described on a national basis (HOLDICH, 2002) and in some cases at a more local scale (SIBLEY et al., 2002). There is however, little information on the within-catchment colonisation and expansion of non-indigenous crayfish populations. With populations of non-indigenous crayfish now present in the majority of catchments in England (SIBLEY, BRICKLAND and BYWATER, 2002) and large numbers of introduced populations of crayfish present across Europe (HOLDICH, 2002) within-catchment range expansion is likely to become of increasing importance as populations of non-indigenous crayfish become established and disperse. Knowledge of the spatial and temporal patterns of species invasions can provide valuable information, which may aid understanding of the invasion mechanisms operating and the likely consequences of the introduction (HACKER et al., 2001; MEINESZ et al., 2001). This knowledge is of key importance in assessing the timescale of the threat that signal crayfish pose to native crayfish populations and the wider aquatic ecosystem, and in the formulation of any possible management strategies.

Here we report the colonisation and expansion of two populations of introduced signal crayfish in upland rivers in Northern England. Both rivers have historically been considered important rivers for the native endangered white-clawed crayfish with extensive and abundant populations reported. The invasion of signal crayfish in one of the rivers has already caused the loss of several white-clawed crayfish sub-populations and their continued expansion has the potential to cause further losses of riverine populations of white-clawed crayfish.

\section{SITE HISTORY AND CHARACTERISTICS}

The rivers Wharfe and Ure are major tributaries of the Yorkshire Ouse that discharges into the Humber estuary on the east coast of England. The Wharfe and Ure both rise as a series of streams at an altitude of over $600 \mathrm{~m}$ in the Pennine Hills (Yorkshire Dales) where they have adjacent catchments. The flows of the upper River Ure and Wharfe are dominated by surface water flow, they are considered flashy with both rivers responding rapidly to rainfall. 
In common with many introductions of signal crayfish the initial introductions in both rivers were made into apparently contained lakes for the purposes of control of aquatic vegetation and supplying the restaurant trade. Populations of signal crayfish developed within these lakes and individuals moved through the outflows to establish wild riverine populations, the expansion of which is described here.

\section{River Wharfe}

Signal crayfish were first introduced into trout fishing lakes adjacent to the River Wharfe in 1983. The lakes are close $(<20 \mathrm{~m})$ to White Beck a tributary of the River Wharfe, and the lake outlet discharges directly into it. Signal crayfish became established in the fishing lakes and moved relatively unhindered through the outflow and via White Beck into the Wharfe. Signal crayfish had become established in White Beck by 1987 and were captured in the River Wharfe at the confluence with White Beck in 1990 (PEAY, 1997). By 1995 signal crayfish were recorded $4.1 \mathrm{~km}$ downstream of the confluence of White Beck with the Wharfe. In 1997 signal crayfish were recorded $9.0 \mathrm{~km}$ downstream of the confluence (PEAY, 1997).

\section{River Ure}

Signal crayfish were introduced into a small trout fishing lake adjacent to the River Ure in the late 1980s. The sole outflow of the fishing lake is a small underground pipe which discharges via a small fish farm into the Ure. Signal crayfish were first recorded in the Ure in 1997, close to where the fish farm discharges. A preliminary survey, involving hand-searching within likely refuges and capturing disturbed crayfish, was undertaken in 1997 (ROGERS, 1998); low numbers of signal crayfish were recorded over a total linear range of $100 \mathrm{~m}$ centred around the discharge pipes (ROGERS, 1998).

\section{METHODS}

All surveying for crayfish within the Ure and Wharfe was conducted by hand searching. Sites were selected that would provide abundant refuges for crayfish and which could be effectively and safely searched by surveyors. All sites that were searched consisted of relatively unembedded cobble and boulder substrate that provided potential refuges in areas of low turbidity and were less than $0.6 \mathrm{~m}$ deep. Survey work was carried out during periods of low discharge when water clarity was high. During searching any crayfish seen were caught if possible. Captured crayfish were identified, sexed, the carapace length measured and any missing or regenerating chelae recorded.

\section{River Wharfe}

In 2001 and 2002 a general survey was carried out in a $40 \mathrm{~km}$ stretch of river around the introduction focus, during 2003 finer scale surveying (approximately $500 \mathrm{~m}$ apart) was carried out at the upstream and downstream extent (approximate location identified in 2001-2002). Surveys were undertaken between May and September in all years, a total of 34 sites were surveyed for crayfish. A combination of timed effort hand-searching (1 person-hr) and fixed area searches was used to survey sites. In fixed area searches (quadrate $0.49 \mathrm{~m}^{2}$ ) a total of between 12.25 and $24.50 \mathrm{~m}^{2}$ of streambed was searched per site.

\section{River Ure}

Surveying was carried out on the River Ure in the area surrounding the source of the introduction of signal crayfish into the river. Surveys were carried out in August September in 2001, 2002 and 2003. At each selected site 0.5 person-hour searches were conducted. A total of 30 sites were searched in 2001, 26 in 2002 and 24 in 2003. Eighteen 
of the selected sites were searched in all years. Sites upstream and downstream of those surveyed in 2001 were included in the surveys during 2002 and 2003 to ensure sampling of the expanding population across its full distribution.

All distances relating to recorded crayfish distributions refer to distances along the midline of the river. Distances from the source of introduction refer to distances upstream and downstream along the Ure and Wharfe. The source of introduction on the River Ure was taken as the midpoint between the two outflows from the fish farm and on the River Wharfe the source of the introduction was taken as the confluence of White Beck with the Wharfe.

\section{RESULTS AND DISCUSSION}

The colonisation of the upper Wharfe by signal crayfish has been rapid. From the first records of signal crayfish in the Wharfe in 1990, the population has now (2003) expanded at least $23.3 \mathrm{~km}$ downstream and $6.1 \mathrm{~km}$ and $4.6 \mathrm{~km}$ upstream in the Skirfare and in the Wharfe respectively (Figure 1) from the source of introduction. This represents an average rate of downstream range expansion of $1.8 \mathrm{~km}_{\text {year }}{ }^{-1}$, and upstream range expansion of $0.47 \mathrm{~km}_{\text {year }}{ }^{1}$ and $0.35 \mathrm{~km}_{\text {year }}{ }^{-1}$ in the Skirfare and Wharfe respectively. The rate of downstream expansion of the signal crayfish population appears to have increased since introduction. In 1997 they were recorded a maximum of $8.9 \mathrm{~km}$ downstream (PEAY, 1997; 1990-1997 downstream expansion $1.27 \mathrm{~km} \mathrm{yr}^{-1}$ ), yet in the next six years the population has colonised a further $14.4 \mathrm{~km}$. (1997-2003 downstream expansion $2.4 \mathrm{~km} \mathrm{yr}^{-1}$; Figure 1). The temporal pattern of upstream colonisation within the Wharfe is unclear with no surveys undertaken between introduction and those reported here.

The current rate of population range expansion in the Wharfe $\left(>2 \mathrm{~km}_{\text {year }}{ }^{-1}\right)$ appears to be high although comparisons with other rivers are difficult due to the lack of published

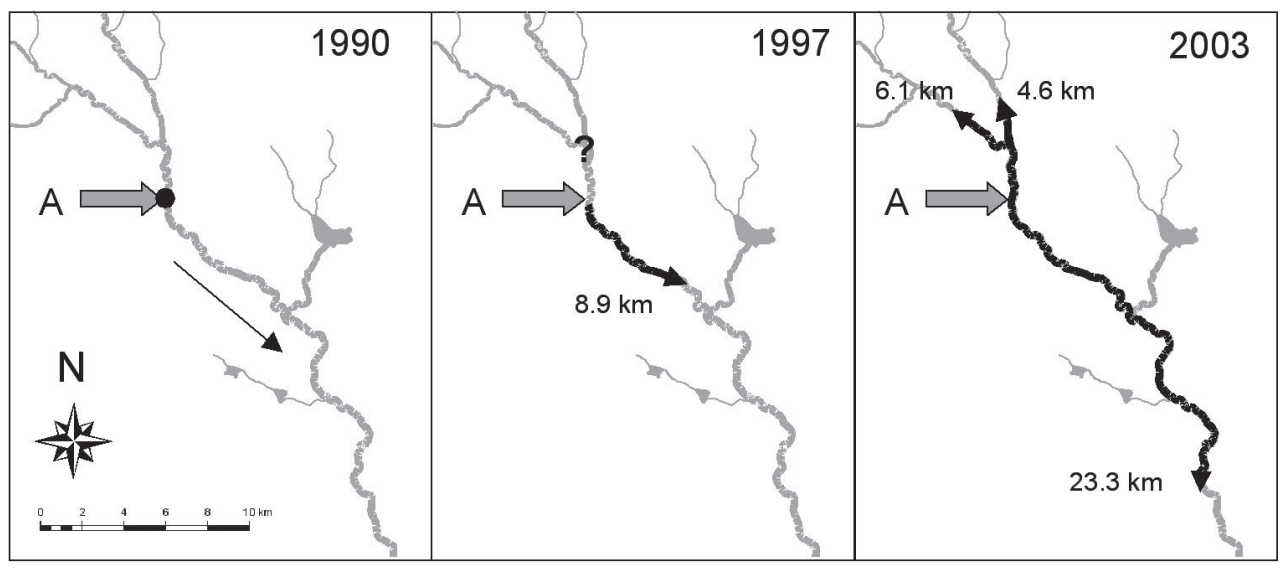

Figure 1

Expansion of the signal crayfish population in the River Wharfe. Arrow A denotes introduction site (1990 first recorded presence of signal crayfish in Wharfe; 1997 downstream distribution data from PEAY (1997); 2003 information from this study).

\section{Figure 1}

Invasion de la population d'écrevisse américaine dans la rivière Wharfe. La flèche A montre le site d'introduction (en 1990, premier enregistrement de la présence de l'écrevisse américaine dans le Wharfe ; en 1997, distribution en aval données de PEAY (1997) ; en 2003, données de cette étude). 
information. Rates of population range expansion of $1 \mathrm{~km}$ year ${ }^{-1}$ have been reported from the River Wreake (HOLDICH, ROGERS and READER, 1995) and $1.1 \mathrm{~km}$ year ${ }^{1}$ from the River Great Ouse (GUAN and WILES, 1999), both lowland rivers in central England.

In contrast to the rapid colonisation of the Wharfe by signal crayfish, the expansion of the population within the Ure appears to be occurring at a slower rate. From initial records of signal crayfish within the Ure in 1996, they have now colonised $0.4 \mathrm{~km}$ upstream and $1.28 \mathrm{~km}$ downstream from the source of introduction. This represents an average rate of downstream expansion of the population of $0.18 \mathrm{~km}_{\text {year }}{ }^{-1}$ and upstream expansion of $0.06 \mathrm{~km}$ year ${ }^{1}$. The rate of population expansion was not constant between 1996-2003. Between 1996 and 2001 the signal crayfish occupied $0.57 \mathrm{~km}$ linear distance, representing an increase in range of $0.12 \mathrm{~km} \mathrm{yr}^{1}$ whilst between 2001 and 2003 the recorded range increased to $1.68 \mathrm{~km}$, an increase in range of $0.55 \mathrm{~km} \mathrm{yr}^{-1}$ between 2001-2003 (Figure 2).

In all years there was a general decline in the numbers of crayfish recorded during each timed search with distance from the source of introduction, in both upstream and downstream directions with a more rapid decline in numbers upstream (Figure 2). At the 18 sites surveyed in 2001 and 2003 there was a significant increase (Wilcoxon Signed Ranks Test, $T=17, P<0.05$ ) in abundance of crayfish between these years.

The comparatively slow rate of expansion of the Ure population may be due to the Ure population currently being in lag phase. Introduced species are frequently observed showing slow initial spread followed by rapid expansion in distribution (SHIGESADA and KAWASAKI, 1997). The slow initial spread of the Ure population contrasts with the apparently fast expansion of the Wharfe population with little apparent lag. This may be attributed to differences in the initial propagule pressure. Although no quantitative information exists on the numbers of crayfish moving from the fishing lakes into the rivers, the access to the Wharfe from the lake population is comparatively unconstrained, by contrast to the situation on the Ure where crayfish have to pass through an underground pipe for $1 \mathrm{~km}$. This is believed to have led to significantly greater numbers of signal crayfish moving into the Wharfe and contributed to comparatively quick establishment and spread of the Wharfe population compared to the situation in the Ure.

On both rivers there was a strong bias towards downstream colonization (upstream: downstream ratio of distance colonized from source of introduction; Wharfe 1:3.8, Ure 1:3.2) with the distance colonized downstream over three times the distance colonised upstream. This contrasts with records from lowland rivers (HOLDICH, ROGERS and READER, 1995; GUAN and WILES, 1999) in which expansion was only weakly biased in a downstream direction. The higher gradient of upland rivers is associated with an increased number of riffles and falls, which whilst not forming an absolute barrier to signal crayfish moving upstream may have a reduced permeability to upstream movements (BUBB, 2004) contributing to the observed reduced upstream expansion. Higher gradient is also associated with higher mean water velocity (WETZEL, 2001), this may potentially also contribute to the downstream bias in colonization.

The downstream expansion in range of signal crayfish in the Wharfe appears to have caused the progressive loss of populations of the native white-clawed crayfish where they come into direct contact. White-clawed crayfish were previously present almost continually through the main river from downstream of the site of signal crayfish introduction (PEAY 1997), but in 2003 were only recorded from $12 \mathrm{~km}$ downstream of the site of introduction. Upstream of the site of signal crayfish introduction the situation is unclear and there are no recent records of white-clawed crayfish. In 2003 an extensive mixed zone of whiteclawed and signal crayfish was recorded. A mixed zone of white-clawed crayfish and signal crayfish was recorded over the lower $14.4 \mathrm{~km}$ of the signal crayfish population. White-clawed crayfish were present downstream of the mixed zone. The change from a signal only population to a white-clawed only population can be described by a logistic curve (Figure 3; $R^{2}=0.988, P<0.0001$ ). 


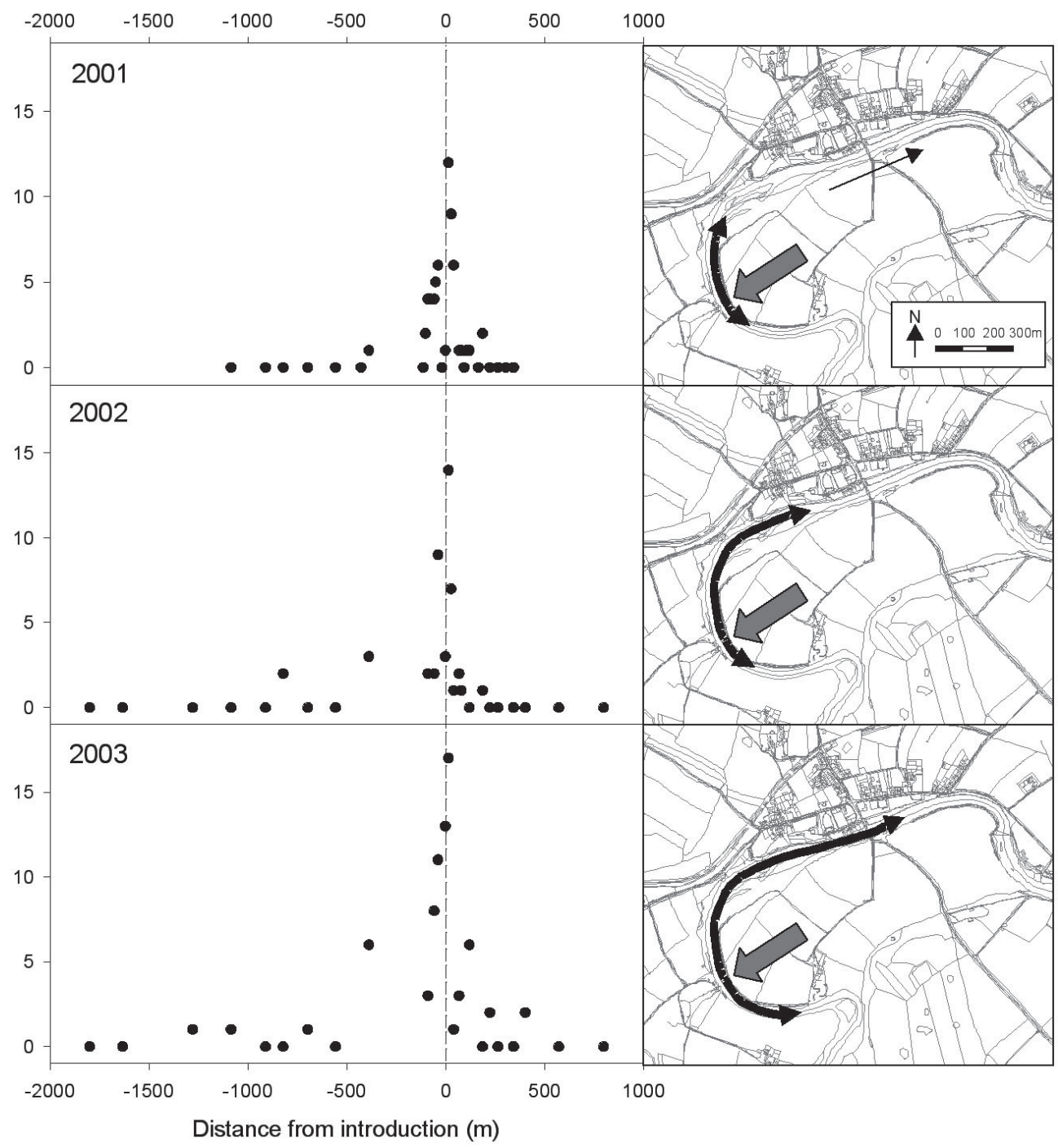

Figure 2.

a - Number of signal crayfish recorded in 2001, 2002 and 2003 during standardised effort ( 0.5 person hours) searches of the Ure, with increasing distance upstream (+ ve) and downstream (- ve) from the source of introduction. b - Maximum recorded upstream and downstream distribution of signal crayfish, River Ure, 2001-2003. Arrow denotes introduction site. Map data ordnance survey.

\section{Figure 2}

a - Nombre d'écrevisses américaines enregistrées en 2001, 2002 et 2003 pendant l'effort normalisé ( 0,5 personne heure) recherche dans l'Ure, avec l'augmentation de la distance en amont (+ ve) et en aval ( - ve) depuis la source d'introduction. b - Distribution maximum de l'écrevisse américaine, enregistrée en amont et en aval, dans la rivière Ure, 2001-2003. La flèche montre le site d'introduction. Carte issue de l'institut national de Grande-Bretagne.

The development of a mixed population of white-clawed and signal crayfish as observed on the Wharfe is relatively uncommon. Although signal crayfish now exist in many waters previously occupied by European crayfish, in most cases the native European crayfish 


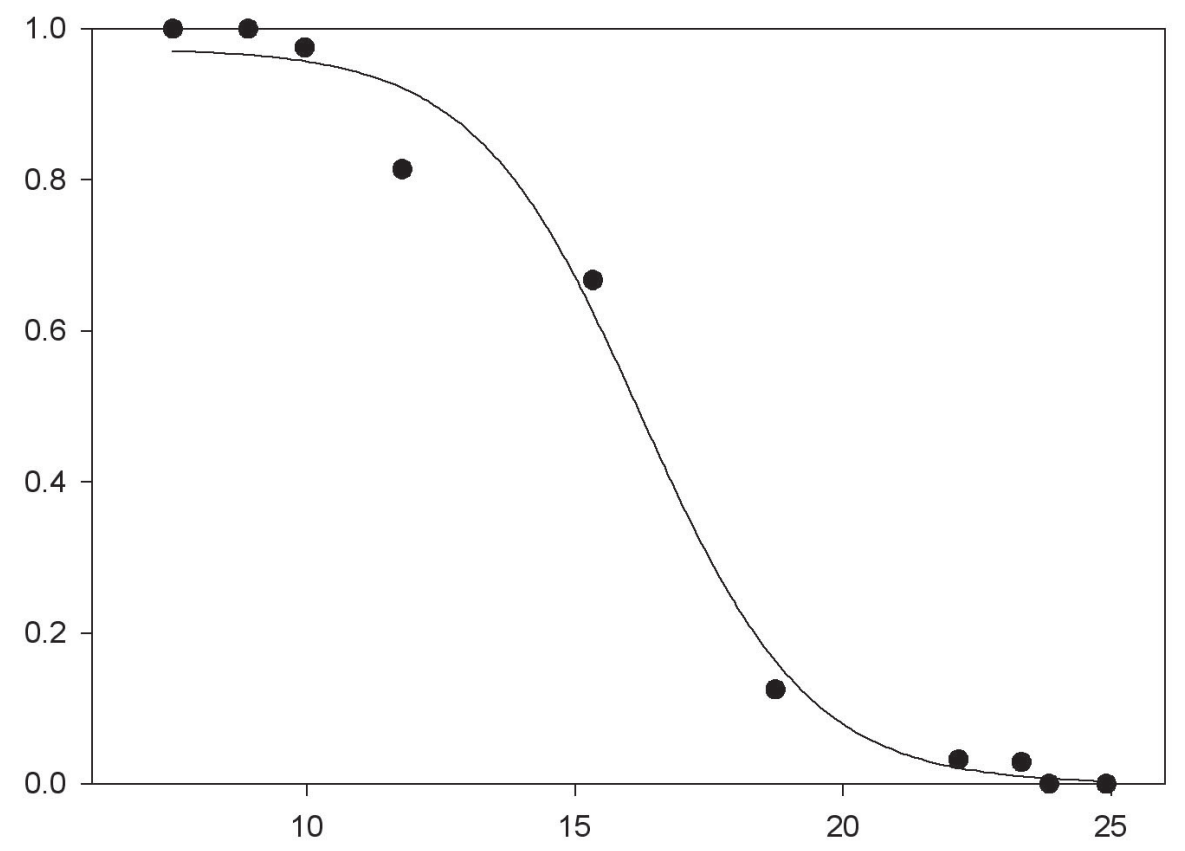

Downstream distance from source of introduction $(\mathrm{km})$

\section{Figure 3}

Change in ratio of signal crayfish to white-clawed crayfish in mixing zone with increasing distance from site of signal crayfish introduction downstream in 2003 in the River Wharfe. (Logistic Curve $r^{2}=0.988, P<0.0001$ ).

\section{Figure 3}

Modification du rapport de l'écrevisse américaine sur l'écrevisse européenne dans une zone mixte, avec croissance des distances du site d'introduction de l'écrevisse américaine en 2003, dans la rivière Wharfe (Courbe logistique $\left.r^{2}=0,988, P<0,0001\right)$.

have been eliminated by crayfish plague Aphanomyces astaci for which signal crayfish have acted as a vector, with little or no direct contact between the two species. In the limited number of cases in which signal crayfish have formed mixed populations with white-clawed crayfish, without any apparent transmission of crayfish plague to white-clawed crayfish, the loss of white-clawed crayfish has occurred over several years $(\mathrm{HOLDICH}, \mathrm{ROGERS}$ and READER, 1995). The local extinction of white-clawed crayfish in the Wharfe appears to occur 6-7 years after the first colonisation by signal crayfish. This rate of extinction of whiteclaws is similar to that described in other mixed populations (HOLDICH, ROGERS and READER, 1995; HOLDICH and DOMANIEWSKI, 1995) although the published information on lotic mixed signal and white-clawed crayfish populations is not very detailed (HOLDICH, ROGERS and READER, 1995). In Europe two mixed populations of apparently plague-free signal crayfish with noble crayfish Astacus astacus have been documented. In a Swedish lake signal crayfish rapidly displaced noble crayfish over a five-year period (SÖDERBÄCK, 1991 ; 1995) whilst in contrast the same two species have cohabited in a Finnish lake for over 20 years (WESTMAN, SAVOLAINEN and PURSIANINEN, 1993).

Further expansion of the signal crayfish populations in the Wharfe and Ure is predicted. This will almost certainly lead to the continued loss of populations of white-clawed crayfish from the main channel of the Wharfe catchment. Populations of white-clawed crayfish are present downstream along the River Wharfe almost as far as the tidal limit (HOLDICH and 
ROGERS, 1995). In contrast to the Wharfe where white-clawed populations are downstream of the signal crayfish population, in the Ure the majority of white-clawed populations are upstream from the signal crayfish population. White-clawed crayfish are abundant several kilometres upstream of the signal crayfish population in the Ure and are widely distributed along the upper Ure and its tributaries (C. Williams pers. com.). The upstream expansion of the signal crayfish population in the Ure seems likely to lead to some direct contact between white-clawed and signal crayfish, with the probable result of loss of sub-populations of white-clawed crayfish. The extent that signal crayfish will continue to colonise upstream is unclear. Several weirs and substantial natural waterfalls occur upstream of the signal crayfish population and below abundant white-clawed crayfish populations. It is possible that these may prevent or slow the upstream expansion of signal crayfish. A detailed understanding of the role of flow and obstructions on the movement and colonisation ability of signal crayfish is required for predictions to be made regarding the upstream colonisation and fate of whiteclawed crayfish in the Ure. Given the comparatively slow upstream colonisation of signal crayfish in both rivers, the greatest immediate threat to populations of white-clawed crayfish in the upper Ure from signal crayfish appears to be from the possibility of new introductions and resultant foci of invasion upstream of the parent signal crayfish population.

\section{ACKNOWLEDGEMENTS}

We are grateful to all who assisted with the survey work and to Sylvie GAUDRON for the French translation. The project was partially funded by Yorkshire Dales National Park Authority and the Environment Agency. DHB was in receipt of a University of Durham studentship.

\section{REFERENCES}

BUBB D.H., 2004. Spatial ecology of white-clawed crayfish Austropotamobius pallipes and signal crayfish Pacifastacus leniusculus in upland rivers, Northern England. PhD thesis, University of Durham, UK, $180 \mathrm{p}$.

DORN N.J. and WOJDAK J.M., 2004. The role of omnivorous crayfish in littoral communities. Oecologia, 140, 150-159.

GUAN R.-Z. and WILES P.R., 1997. Ecological impact of introduced crayfish on benthic fishes in a British lowland river. Conservation Biol., 11, 641-417.

GUAN R.-Z. and WILES P.R., 1999. Growth and reproduction of the introduced crayfish Pacifastacus leniusculus in a British lowland river. Fisheries Research, 42, 245-259.

HACKER S.D., HEIMER D., HELLQUIST C.E., REEDER T.G., REEVES B., RIORDAN T.J., DETHIER M.N., 2001. A marine plant (Spartina anglica) invades widely varying habitats: potential mechanisms of invasion and control. Biological Invasions, 3, 211217.

HENTTONEN P. and HUNER J.V., 1999. The introduction of alien species of crayfish in Europe: a historical introduction. In: Crayfish in Europe as alien species: how to make the best of a bad situation? GHERARDI F., HOLDICH D.M. (Eds), 13-22, A.A. Balkema, Rotterdam.

HOLDICH D.M., 1999. The negative effects of established crayfish introductions. In: Crayfish in Europe as alien species: how to make the best of a bad situation? GHERARDI F., HOLDICH D.M. (Eds), 31-49, A.A. Balkema, Rotterdam.

HOLDICH D.M., 2002. Distribution of crayfish in Europe and some adjoining countries. Bull. Fr. Pêche Piscic, 367, 611-650.

HOLDICH D.M. and DOMANIEWSKI J.C.J., 1995. Studies on a mixed population of the crayfish Austropotamobius pallipes and Pacifastacus leniusculus in England. Freshwater Crayfish, 10, 37-45. 
HOLDICH D.M. and ROGERS W.D., 1995. Crayfish survey of the River Wharfe. University of Nottingham.

HOLDICH D.M., ROGERS W.D. and READER J.P., 1995. Crayfish Conservation. National Rivers Authority Research and Development Report 378. Bristol, UK.

HOLDICH D.M., ROGERS W.D. and REYNOLDS J.D., 1999. Native and alien crayfish in the British Isles. In: Crayfish in Europe as alien species: how to make the best of a bad situation? GHERARDI F., HOLDICH D.M. (Eds), 221-236, A.A. Balkema, Rotterdam.

MEINESZ A., BELSHER T., THIBAUT T., ANTOLIC B., MUSTAPHA K.B., BOUDOURESQUE C.-F., CHIAVERINI D., CINELLI F., COTTALORDA J.-M., DJELLOULI A., ABED A.E., ORESTANO C., GRAU A.M., IVESA L., JAKLIN A., LANGAR H., MASSUTIPASCUAL E., PEIRANO A., TUNESI L., VAUGELAS J., ZAVODNIK N., ZULJEVIC A., 2001. The introduced green alga Caulerpa taxifolia continues to spread in the Mediterranean. Biological Invasions, 3, 201-210.

NYSTRÖM P., 1999. Ecological impact of introduced and native crayfish on freshwater communities: European perspectives. In: Crayfish in Europe as alien species: how to make the best of a bad situation? GHERARDI F., HOLDICH D.M. (Eds), 87-106, A.A. Balkema, Rotterdam.

NYSTRÖM P., 2002. Ecology. In: Biology of Freshwater Crayfish. HOLDICH D.M. (Ed), 192235. Blackwell Scientific, Oxford.

NYSTRÖM P. and STRAND J.A., 1996. Grazing by a native and an exotic crayfish on aquatic macrophytes. Freshwater Biol., 36, 673-682.

PEAY S., 1997. Night survey for crayfish in the River Wharfe, Yorkshire. Masters Thesis, University of Hull, UK, p. 120.

ROGERS D., 1998. Investigation of a signal crayfish escape from West Tanfield to the River Ure. David Rogers Associates, Donnington (unpublished report).

SHIGESADA N. and KAWASAKI K., 1997. Biological invasions: theory and practice. Oxford University Press, Oxford, p. 205.

SIBLEY P.J., BRICKLAND J.H. and BYWATER J.A., 2002. Monitoring the distribution of crayfish in England and Wales. Bull. Fr. Pêche Piscic., 367, 833-844.

SÖDERBÄCK B., 1991. Interspecific dominance relationship and aggressive interactions in the freshwater crayfishes Astacus astacus (L.) and Pacifastacus leniusculus (Dana). Canadian Jour. Zool., 69, 1321-1325.

SÖDERBÄCK B., 1995. Replacement of the native crayfish Astacus astacus by the introduced species Pacifastacus leniusculus in a Swedish lake: possible causes and mechanisms. Freshwater Biol., 33, 291-304.

STATZNER B., PELTRET O. and TOMANOVA S., 2003. Crayfish as geomorphologic agents and ecosystem engineers: effect of a biomass gradient on baseflow and floodinduced transport of gravel and sand in experimental streams. Freshwater Biol., 48, 147-163.

WESTMAN K., SAVOLAINEN R. and PURSIANINEN M., 1993. A comparative study of the growth and moulting of the noble crayfish, Astacus astacus (L.) and the signal crayfish, Pacifastacus leniusculus (Dana), in a small forest lake in southern Finland. Freshwater Crayfish, 9, 451-465.

WETZEL R.G., 2001. Limnology, lake and river ecosystems (3 ${ }^{\text {rd }}$ Edition). Academic Press, San Diego, p. 1006. 
